\title{
CHEMICAL, GRANULOMETRIC AND TECHNOLOGICAL CHARACTERISTICS OF WHOLE FLOURS FROM COMMERCIAL CULTIVARS OF COWPEA ${ }^{1}$
}

\author{
MAIARA JAIANNE BEZERRA LEAL RIOS ${ }^{2}$, KAESEL JACKSON DAMASCENO-SILVA ${ }^{3 *}$, REGILDA SARAIVA \\ DOS REIS MOREIRA-ARAÚJO ${ }^{4}$, EVÂNIA ALTINA TEIXEIRA DE FIGUEIREDO ${ }^{5}$, MAURISRAEL DE MOURA \\ ROCHA $^{3}$, JORGE MINORU HASHIMOTO ${ }^{3}$
}

\begin{abstract}
Flour production through milling is an alternative for the cowpea processing, when the aim is to obtain a product with higher added value. The objective of this work was to determine the chemical composition, the granulometry, and evaluate the microbiological characteristics of whole-bean flours from five cowpea cultivars (BRS Cauamé, BRS Guariba, BRS Xiquexique, BRS Novaera and BRS Itaim). Cowpea beans were dried in a oven (Fanem, 320-SE) at $50{ }^{\circ} \mathrm{C}$ for 6 hours, milled in a cyclone-type rotor mill (Tecnal, TE$651 / 2$ ) and, subsequently, in a pulverizer-type semi-industrial mill (Fritsch, Pulverisette 14) to obtain the flour. The flour centesimal composition, total energetic value, mineral content, granulometry, microbiological characteristics, and technological properties-flour water absorption and solubility in water-were analyzed. All analyzes were performed in triplicate and the results expressed in mean \pm standard deviation. The means were compared by the Scott-Knott test $(p \leq 0.05)$. The flour centesimal composition presented ( $\mathrm{g}$ per $100 \mathrm{~g}$ of flour): 7.13 to 10.33 of moisture, 2.06 to 3.65 of ashes, $1.53 \mathrm{~g}$ to 2.90 of lipids, 21.73 to 25.77 of proteins, and 58.08 to 64.02 of carbohydrate. The flours had on average $359.04 \mathrm{Kcal}(100 \mathrm{~g})$ and presented high iron, zinc, copper, manganese, phosphorus and magnesium contents. The whole-bean flours from the cultivars BRS Cauamé and BRS Xiquexique are sources of calcium. Regarding the microbiological characteristics, all flours are innocuous. The water absorption index were within 1.77 and $2.20 \mathrm{~g} \mathrm{~g}^{-1}$ and the water solubility index within 17 and $23 \%$. All whole-bean flours had good nutritional, technological and microbiological characteristics, and thus potential for use in bakery products.
\end{abstract}

Keywords: Vigna unguiculata. Cowpea flour. Chemical composition.

\section{CARACTERIZAÇÃO QUÍMICA, GRANULOMÉTRICA E TECNOLÓGICA DE FARINHAS INTEGRAIS DE CULTIVARES COMERCIAIS DE FEIJÃO-CAUPI}

\begin{abstract}
RESUMO - A produção de farinha por meio da moagem é uma alternativa para o processamento do feijãocaupi, na busca de um produto com maior valor agregado. Objetivou-se determinar a composição química, a granulometria e avaliar microbiologicamente farinhas integrais de cinco cultivares (BRS Cauamé, BRS Guariba, BRS Xiquexique, BRS Novaera e BRS Itaim) comerciais de feijão-caupi. Para a obtenção das farinhas procedeu-se a secagem dos grãos em estufa (marca Fanem, modelo 320-SE) a $50{ }^{\circ} \mathrm{C}$, por 6 horas; com posterior moagem, primeiramente em moinho de facas tipo ciclone (marca Tecnal, modelo TE-651/2) e posteriormente, em moinho semi-industrial tipo pulverizador (marca Fritsch, modelo Pulverisette 14). Analisaram-se a composição centesimal, o valor energético total, o conteúdo mineral, a granulometria, as características microbiológicas, e as tecnológicas quanto a absorção e solubilidade em água das farinhas. As análises foram realizadas em triplicata e os resultados expressos em média \pm desvio padrão. As médias foram comparadas pelo teste de Scott-Knott $(\mathrm{p} \leq 0,05)$. Os valores encontrados para composição centesimal foram: umidade entre 7,13 a $10,33 \mathrm{~g} / 100 \mathrm{~g}$; cinzas de 2,06 a 3,65 g/100g; lipídios variaram de 1,53 g a 2,90 g/100g; proteínas entre 21,73 a $25,77 \mathrm{~g} / 100 \mathrm{~g}$ e o conteúdo de carboidratos variou de 58,08 a 64,02 g/100g. As farinhas ofertaram em média $359,04 \mathrm{Kcal} / 100 \mathrm{~g}$ e apresentaram elevado teor de ferro, zinco, cobre, manganês, fósforo e magnésio, sendo as das cultivares BRS Cauamé e BRS Xiquexique fontes de cálcio. Sob o aspecto microbiológico as farinhas apresentaram-se inócuas. Os valores de IAA variaram de 1,77 a 2,20 g/g e ISA de 17 a 23\%. Concluiu-se que todas as farinhas apresentaram bom perfil nutritivo, tecnológico e microbiológico, apresentando, portanto potencial para utilização no desenvolvimento de produtos de panificação.
\end{abstract}

Palavras-chave: Vigna unguiculata. Farinha de feijão-caupi. Composição química. 


\section{INTRODUCTION}

Cowpea (Vigna unguiculata (L.) Walp.) is one of the main crops in the Northeast region of Brazil, especially in the states of Ceará and Piauí, where it is the main subsistence crop for rural populations, an important component of the population's diet, and an important generator of employment and income (MOUSINHO; ANDRADE JÚNIOR; FRIZZONE, 2008).

Several cowpea cultivars have been developed through classical genetic improvement. The development of the first cultivars in Brazil sought to increase grain yield, subsequently, resistance to diseases, and, currently, it has been focused in grain nutritional quality and plant architecture (FREIRE FILHO et al., 2005).

The flour production by milling is an alternative for the cowpea processing (GOMES; REIS; SILVA, 2012). Cowpea flour can be introduced to the diet of people of different age, by improving several food products, such as baked products, cookies and pasta, raising their protein quality (FROTA et al., 2010).

Considering the cowpea high nutritive value, low production cost and the use of its flour is processed foods, partially substituting wheat flour, the objective of this work was to determine the chemical composition and granulometry, and evaluate the microbiological characteristics of whole-bean flours from five cowpea cultivars and their potential for use in bakery products.

\section{MATERIAL AND METHODS}

Five cowpea commercial cultivars were evaluated: BRS Cauamé, BRS Guariba, BRS Xiquexique, BRS Novaera and BRS Itaim. These cultivars were from the Embrapa Mid-North, in Teresina in the state of Piauí, Brazil $\left(05^{\circ} 05^{\prime} \mathrm{S}\right.$, $42^{\circ} 48^{\prime} \mathrm{W}$ and $72 \mathrm{~m}$ altitude; hot sub-humid tropical climate). The grains used were from the lot of December 2012.

The whole-bean flour processing and chemical and microbiological analyzes were performed in the Laboratory of Bromatology and Food Biochemistry of the Federal University of Piauí, Laboratory of Bromatology of the Embrapa Mid-North, and Laboratory of Food Microbiology of the Federal University of Ceará. This study was carried out from May 2013 to March 2014.

The bean flour processing consisted of drying the grains in a forced air circulation oven (Fanem, 320 -SE) at $50{ }^{\circ} \mathrm{C}$ for 6 hours, and milled them in a cyclone-type rotor mill (Tecnal, TE-651/2) and subsequently in a pulverizer-type semi-industrial mill (Fritsch, Pulverisette 14). The flour granulometry was similar to that of wheat flour, according to the methodology described by Frota et al. (2010). The flours were packed in polyethylene packages and stored at $-18{ }^{\circ} \mathrm{C}$ until chemical analyzes. The flour samples used for the microbiological analyzes were kept at room temperature to avoid freezing affecting the results.

The moisture was determined by gravimetry in an oven at $105{ }^{\circ} \mathrm{C}$. The ash contents were determined by incineration in a muffle at $550{ }^{\circ} \mathrm{C}$. The lipid fraction was determined by extraction with hexane p.a. solvent in a Soxhlet intermittent extractor. Protein analyzes were based on nitrogen determination by the Kjeldahl method, using the conversion factor 6.25 . Carbohydrate contents were determined by difference between the other constituents and the centesimal composition. The centesimal composition analyzes were carried out in triplicate, according to the Horwitz and Latimer Jr. (2011) methodology.

The energy value was calculated according to Watt and Merril (1963), using Atwater conversion factors (carbohydrates $=4.0, \quad$ lipids $=9.0$, proteins $=4.0$ ).

Phosphorus content was determined by colorimetry, according to the method described by Silva and Queiroz (2002). Other minerals-iron, zinc, copper, manganese, calcium and magnesiumwas determined by flame atomic absorption spectrophotometry (SILVA, 1981).

The flour granulometry was determined with a device consisting of five sieves and a vibratory base (Tamizador Produtest). The mesh opening diameters of the sieves were $0.125,0.25,0.5,1.0$ and $2.0 \mathrm{~mm}$. The flour samples were placed in these sieves and subjected to vibration with the rheostat adjusted at speed 5 for 10 minutes, then, the flour retained in each sieve was weighed (CEREDA; CATÂNEO, 1986).

The mean particle diameter was determined by the method described by Henderson and Perry (1976), using the formula: $D=104.14 \times 2 F M$, wherein $D$ is the mean diameter of the particle $(\mu \mathrm{m})$ and $F M$ is the fineness modulus - the sum of the retained fractions accumulated in each sieve divided by $100(F M=\Sigma \%$ retained accumulated $/ 100)$.

The microbiological analyzes were carried out in the Laboratory of Food Microbiology of the Department of Food Technology of the Federal University of Ceará. Flour samples (300 grams) of each cowpea cultivar were weighed in analytical balance, and packed in sterile packages and sent to this laboratory soon after milling. The coliform contents at $45^{\circ} \mathrm{C}$, Bacillus cereus and Salmonella spp. were determined following the methodology proposed by Rice et al. (2012).

The data was subjected to statistical analyzes in the software Sisvar-5.3 of the Federal University of Lavras (FERREIRA, 2008). The means were compared by the Scott-Knott test at 5\% significance.

The water absorption index (WAI) and water 
solubility index (WSI) were obtained in triplicates, following the methodology described by Anderson et al. (1969).

\section{RESULTS AND DISCUSSION}

According to the Brazilian legislation, the moisture content of flours must not exceed $15 \%$ (AGÊNCIA NACIONAL DE VIGILÂNCIA
SANITÁRIA, 2005). The flour moisture contents found in the samples ranged from 7.13 to $10.33 \mathrm{~g} / 100 \mathrm{~g}$ (Table 1). The moisture content of the flours presented statistical differences $(p>0.05)$, except the flours from the cultivars BRS Guariba $(10.33 \mathrm{~g} / 100 \mathrm{~g})$ and BRS Novaera (10.28 g/100 g). Thus, the moisture contents found in this study are in accordance with the Brazilian legislation. Frota, Soares and Arêas (2008) found lower moisture content $(6.0 \mathrm{~g} / 100 \mathrm{~g})$ in whole-bean flour from the cowpea cultivar BRS Milênio.

Table 1. Centesimal composition of whole-bean flours from five cowpea commercial cultivars.

\begin{tabular}{lccccc}
\hline \multicolumn{1}{c}{ Cultivars } & $\begin{array}{c}\text { Moisture } \\
\mathrm{g} / 100 \mathrm{~g}\end{array}$ & $\begin{array}{c}\text { Ashes } \\
\mathrm{g} / 100 \mathrm{~g}\end{array}$ & $\begin{array}{c}\text { Lipids } \\
\mathrm{g} / 100 \mathrm{~g}\end{array}$ & $\begin{array}{c}\text { Proteins } \\
\mathrm{g} / 100 \mathrm{~g}\end{array}$ & $\begin{array}{c}\text { Carbohydrates } \\
\mathrm{g} / 100 \mathrm{~g}\end{array}$ \\
\hline BRS Cauamé & $7.13 \pm 0.03 \mathrm{~d}$ & $3.43 \pm 0.05 \mathrm{a}$ & $1.53 \pm 0.29 \mathrm{~b}$ & $23.88 \pm 0.13 \mathrm{c}$ & $64.02 \pm 0.16 \mathrm{a}$ \\
BRS Guariba & $10.33 \pm 0.27 \mathrm{~b}$ & $3.53 \pm 0.03 \mathrm{a}$ & $2.79 \pm 0.03 \mathrm{a}$ & $25.27 \pm 0.04 \mathrm{a}$ & $58.08 \pm 0.22 \mathrm{~d}$ \\
BRS & $9.66 \pm 0.16 \mathrm{c}$ & $3.65 \pm 0.03 \mathrm{a}$ & $2.17 \pm 0.17 \mathrm{~b}$ & $23.50 \pm 0.09 \mathrm{~d}$ & $61.02 \pm 0.32 \mathrm{c}$ \\
Xiquexique & & & & & \\
BRS Novaera & $10.28 \pm 0.06 \mathrm{~b}$ & $2.06 \pm 0.04 \mathrm{~b}$ & $2.90 \pm 0.34 \mathrm{a}$ & $21.73 \pm 0.01 \mathrm{e}$ & $62.18 \pm 0.42 \mathrm{~b}$ \\
BRS Itaim & $11.19 \pm 0.39 \mathrm{a}$ & $2.27 \pm 0.01 \mathrm{~b}$ & $2.08 \pm 0.57 \mathrm{~b}$ & $24.71 \pm 0.20 \mathrm{~b}$ & $58.61 \pm 0.90 \mathrm{~d}$ \\
\hline \multicolumn{1}{c}{ *CV (\%) } & 2.73 & 26.64 & 12.70 & 0.62 & 0.70 \\
Average overall & 7.34 & 3.17 & 2.46 & 24.45 & 62.38 \\
\hline
\end{tabular}

Means followed by the same lowercase letter in the columns did not statistically differ by the Scott-Knott test $(p \geq 0.05)$; The data are presented as mean $(\mathrm{n}=3) \pm$ standard deviation; $\mathrm{CV}=$ coefficient of variation.

The flour ash contents ranged from 2.06 to $3.65 \mathrm{~g} / 100 \mathrm{~g}$. These results confirm those found by Frota, Soares and Arêas (2008) who reported $2.6 \mathrm{~g} / 100 \mathrm{~g}$ of ashes in the whole-bean flour from the cowpea cultivar BRS Milênio. However, Frota et al. (2010) found $3.14 \mathrm{~g} / 100 \mathrm{~g}$ of ash in flour from peeled cowpea beans (cultivar BR 3-Tracuateua).

According to Lacerda et al. (2006), several factors may affect the amount of ash in grains, such as plant type, concentration of these compounds in the soil, soil salinity index, growth conditions, and plant development stage.

The lipid content in beans is usually lower than other macronutrients (RAMÍREZ-CÁRDENAS, 2006). The lipid contents found in the flours evaluated (Table 1) ranged from 1.53 to $2.90 \mathrm{~g} / 100 \mathrm{~g}$. These results were similar to those reported by Frota, Soares and Arêas (2008), who found $2.2 \mathrm{~g} / 100 \mathrm{~g}$ of lipids in the whole-bean flour from the cowpea cultivar BRS Milênio. Frota et al. (2010) found lower lipid content $(1.49 \mathrm{~g} / 100 \mathrm{~g})$ in flour from peeled cowpea beans (cultivar BR 3-Tracuateua).

The flour protein contents differed statistically ( $p \leq 0.05)$ among the cultivars evaluated. The flour from the cultivar BRS Guariba had the highest concentration of protein $(25.27 \mathrm{~g} / 100 \mathrm{~g})$. Frota, Soares and Arêas (2008) found $24.5 \mathrm{~g} / 100 \mathrm{~g}$ of proteins in the whole-bean flour from the cowpea cultivar BRS Milênio. Gomes, Reis and Silva (2012) reported $26.4 \mathrm{~g} / 100 \mathrm{~g}$ of protein in cowpea whole-bean flour, while Frota et al. (2010) found $24.28 \mathrm{~g} / 100 \mathrm{~g}$ in flour from peeled cowpea beans (cultivar BR 3-Tracuateua).

The carbohydrate contents in the flours from the cultivars evaluated ranged from 58.08 to $64.02 \mathrm{~g} / 100 \mathrm{~g}$, and the flour from the cultivar BRS Cauamé presented the highest carbohydrate content. Frota, Soares and Arêas (2008) found $51.4 \mathrm{~g} / 100 \mathrm{~g}$ of carbohydrates in the whole-bean flour from the cowpea cultivar BRS Milênio, which is lower than that found in this study.

The flour from the cultivars evaluated presented very similar Total Energy Value - TEV, ranging from 352.0 to $365.4 \mathrm{Kcal} / 100 \mathrm{~g}$ (Table 2), denoting the high-energy value of the whole-bean flours. Frota, Soares and Arêas (2008) found a TEV of $323.4 \mathrm{Kcal} / 100 \mathrm{~g}$ in the whole-bean flour from the cowpea cultivar BRS-Milênio. Castilho, Fontanari and Batistuti (2010) reported a TEV of $356.65 \mathrm{Kcal} / 100 \mathrm{~g}$ for the whole-bean flour from pigeonpea (Cajanus cajan L. Millsp.), but Frota et al. (2010) found a TEV of $355.57 \mathrm{Kcal} / 100 \mathrm{~g}$ in flour from peeled cowpea beans (cultivar BR 3-Tracuateua). 
M. J. B. L. RIOS et al.

Table 2. Total Energy Value (TEV) of whole-bean flours from five cowpea commercial cultivars.

\begin{tabular}{lc}
\hline Cultivars & TEV $($ Kcal/100g) \\
\hline BRS Cauamé & 365.4 \\
BRS Guariba & 358.5 \\
BRS Xiquexique & 357.6 \\
BRS Novaera & 361.7 \\
BRS Itaim & 352.0 \\
\hline
\end{tabular}

The flours presented iron contents of 4.48 to $6.56 \mathrm{mg} / 100 \mathrm{~g}$ (Table 3), and the flour from the cultivar BRS Guariba had the highest iron content. Frota, Soares and Arêas (2008) found similar iron content $(6.8 \mathrm{mg} / 100 \mathrm{~g})$ in the whole-bean flour from the cowpea cultivar BRS Milênio. On the other hand, Frota et al. (2010) found iron content of $4.52 \mathrm{mg} / 100 \mathrm{~g}$ in flour from peeled cowpea beans (cultivar BR 3-Tracuateua).

Table 3. Micromineral content in whole-bean flours from five commercial cowpea cultivars.

\begin{tabular}{lcccc}
\hline Cultivars & $\begin{array}{c}\text { Iron } \\
(\mathrm{mg} / 100 \mathrm{~g})\end{array}$ & $\begin{array}{c}\text { Zinc } \\
(\mathrm{mg} / 100 \mathrm{~g})\end{array}$ & $\begin{array}{c}\text { Copper } \\
(\mathrm{mg} / 100 \mathrm{~g})\end{array}$ & Manganese (mg/100g) \\
\hline BRS Cauamé & $5.42 \pm 1.06 \mathrm{~b}$ & $4.13 \pm 0.41 \mathrm{~b}$ & $0.40 \pm 0.02 \mathrm{~b}$ & $1.17 \pm 1.02 \mathrm{~b}$ \\
BRS Guariba & $6.56 \pm 0.70 \mathrm{a}$ & $4.16 \pm 0.44 \mathrm{~b}$ & $0.33 \pm 0.00 \mathrm{c}$ & $1.54 \pm 0.02 \mathrm{~b}$ \\
BRS Xiquexique & $5.27 \pm 0.08 \mathrm{~b}$ & $4.72 \pm 0.10 \mathrm{a}$ & $0.43 \pm 0.01 \mathrm{~b}$ & $2.03 \pm 0.07 \mathrm{a}$ \\
BRS Novaera & $4.48 \pm 0.12 \mathrm{c}$ & $3.17 \pm 0.18 \mathrm{c}$ & $0.55 \pm 0.01 \mathrm{a}$ & $1.49 \pm 0.10 \mathrm{~b}$ \\
BRS Itaim & $5.40 \pm 0.15 \mathrm{~b}$ & $5.14 \pm 0.52 \mathrm{a}$ & $0.59 \pm 0.01 \mathrm{a}$ & $1.25 \pm 0.00 \mathrm{~b}$ \\
\hline *CV (\%) & 9.56 & 6.87 & 4.61 & 21.20 \\
Average overall & 4.80 & 4.29 & 0.48 & 1.56 \\
\hline
\end{tabular}

Means followed by the same lowercase letter in the columns did not statistically differ by the Scott-Knott test $(p \geq 0.05)$; The data are presented as mean $(\mathrm{n}=3) \pm$ standard deviation; $\mathrm{CV}=$ coefficient of variation.

The flour zinc contents found ranged from 3.17 to $5.14 \mathrm{mg} / 100 \mathrm{~g}$ (Table 3), confirming those found by Frota, Soares and Arêas (2008) in the whole-bean flour from the cowpea cultivar BRS Milênio (4.1 mg/100 g). Simplício (2013) reported the similar content $(3.50 \mathrm{mg} / 100 \mathrm{~g})$ for flours from peeled cowpea beans of the cultivars BRS Aracê and BRS Tumucumaque; and Frota et al. (2010) found $3.74 \mathrm{mg} / 100 \mathrm{~g}$ of zinc content in flour from peeled cowpea beans (cultivar BR 3-Tracuateua).

The flour copper contents ranged from 0.33 to $0.59 \mathrm{mg} / 100 \mathrm{~g}$ (Table 3). The flours from the BRS Novaera and BRS Itaim presented significantly higher copper content $(p \leq 0.05)$ than those from the other cultivars. The copper content found by Simplício (2013) for peeled cowpea beans was 0.38 (BRS Aracê) and $0.43 \mathrm{mg} / 100 \mathrm{~g}$ (BRS Tumucumaque).

The flour manganese contents ranged from 1.17 to $2.03 \mathrm{mg} / 100 \mathrm{~g}$, with significantly higher $(p \leq 0.05)$ contents in the flour from the cultivar BRS Xiquexique, compared with those from the other cultivars evaluated (Table 3). Frota, Soares and Arêas (2008) found $1.5 \mathrm{mg} / 100 \mathrm{~g}$ of manganese in the whole-bean flour from the cowpea cultivar BRS Milênio, and Simplício (2013) found 1.77 (BRS Aracê) and $1.85 \mathrm{mg} / 100 \mathrm{~g}$ (BRS Tumucumaque).

The phosphorus content in the cowpea flours ranged from 414.0 to $450.33 \mathrm{mg} / 100 \mathrm{~g}$ (Table 4). These results were lower than that found by Frota, Soares and Arêas (2008) in the whole-bean flour from the cowpea cultivar BRS Milênio
(510 mg/100 g). Simplício (2013) also found higher phosphorus content $(562.0 \mathrm{mg} / 100 \mathrm{~g})$ than those found in this work, in flour from peeled cowpea beans (BRS Aracê); however the phosphorus content in flour from peeled cowpea beans of the BRS Tumucumaque was $490.0 \mathrm{mg} / 100 \mathrm{~g}$, close to those found in this study. Frota et al. (2010) also reported similar results to those of found in this work, presenting phosphorus content of $437 \mathrm{mg} / 100 \mathrm{~g}$ in flour from peeled cowpea beans (cultivar BR 3-Tracuateua).

The flour calcium contents ranged from 143.83 to $160.69 \mathrm{mg} / 100 \mathrm{~g}$, with the highest content in the flour from the cultivar BRS Cauamé. Similar results were reported by Frota, Soares and Arêas (2008), who found $140.00 \mathrm{mg} / 100 \mathrm{~g}$ of calcium in the whole-bean flour from the cowpea cultivar BRS Milênio. Simplício (2013) found calcium contents of 39.0 (BRS Aracê) and $40.0 \mathrm{mg} / 100 \mathrm{~g}$ (BRS Tumucumaque) in flours from peeled cowpea beans.

The flour magnesium contents ranged from 128.6 to $167.17 \mathrm{mg} / 100 \mathrm{~g}$ (BRS Guariba).

According to the technical regulation regarding complementary nutritional information (AGÊNCIA NACIONAL DE VIGILÂNCIA SANITÁRIA, 2012), when a food provides at least $15 \%$ of the Dietary Reference Intake (DRI) of a given nutrient, this food is a source of this nutrient; and when a food provides at least $30 \%$ of the DRI of a given nutrient, this food has a high content of this nutrient. 
M. J. B. L. RIOS et al.

Table 4. Macromineral content in whole-bean flours from five cowpea commercial cultivars.

\begin{tabular}{lccc}
\hline Cultivars & Phosphorus $(\mathrm{mg} / 100 \mathrm{~g})$ & Calcium $(\mathrm{mg} / 100 \mathrm{~g})$ & Magnesium $(\mathrm{mg} / 100 \mathrm{~g})$ \\
\hline BRS Cauamé & $414.0 \pm 5.29 \mathrm{~b}$ & $160.69 \pm 9.49 \mathrm{a}$ & $150.35 \pm 1.14 \mathrm{c}$ \\
BRS Guariba & $450.33 \pm 17.95 \mathrm{a}$ & $143.83 \pm 2.35 \mathrm{~b}$ & $167.17 \pm 2.74 \mathrm{a}$ \\
BRS Xiquexique & $434.0 \pm 7.55 \mathrm{a}$ & $150.10 \pm 2.89 \mathrm{~b}$ & $157.96 \pm 2.96 \mathrm{~b}$ \\
BRS Novaera & $415.33 \pm 13.20 \mathrm{~b}$ & $140.81 \pm 2.11 \mathrm{~b}$ & $128.26 \pm 3.11 \mathrm{~d}$ \\
BRS Itaim & $421.33 \pm 8.50 \mathrm{~b}$ & $148.61 \pm 2.00 \mathrm{~b}$ & $154.95 \pm 1.02 \mathrm{~b}$ \\
\hline *CV (\%) & 2.45 & 3.90 & 1.51 \\
Average overall & 442.40 & 137.69 & 144.38 \\
\hline
\end{tabular}

Means followed by the same lowercase letter in the columns did not statistically differ by the Scott-Knott test $(p \geq 0.05)$; The data are presented as mean $(\mathrm{n}=3) \pm$ standard deviation; $\mathrm{CV}=$ coefficient of variation.

Table 5. Adequacy percentage of minerals in whole-bean flours from five cowpea commercial cultivars to the Dietary Reference Intake (DRI) for adults.

\begin{tabular}{lccccccc}
\hline Cultivars & $\begin{array}{c}\text { Iron } \\
(\%)\end{array}$ & $\begin{array}{c}\text { Zinc } \\
(\%)\end{array}$ & $\begin{array}{c}\text { Copper } \\
(\%)\end{array}$ & $\begin{array}{c}\text { Manganese } \\
(\%)\end{array}$ & $\begin{array}{c}\text { Phosphorus } \\
(\%)\end{array}$ & $\begin{array}{c}\text { Calcium } \\
(\%)\end{array}$ & $\begin{array}{c}\text { Magnesium } \\
(\%)\end{array}$ \\
\hline BRS Cauamé & 38.71 & 59.00 & 44.44 & 50.87 & 59.14 & 16.07 & 57.83 \\
BRS Guariba & 46.86 & 59.43 & 36.67 & 66.95 & 64.33 & 14.38 & 64.30 \\
BRS Xiquexique & 37.64 & 67.43 & 47.80 & 88.26 & 62.00 & 15.01 & 60.75 \\
BRS Novaera & 32.00 & 45.29 & 61.11 & 64.78 & 59.33 & 14.08 & 49.33 \\
BRS Itaim & 38.57 & 73.43 & 65.55 & 54.35 & 60.19 & 14.86 & 59.60 \\
\hline
\end{tabular}

*Dietary Reference Intake (AGÊNCIA NACIONAL DE VIGILÂNCIA SANITÁRIA, 2012).

According to the flour adequacy percentages to the DRI for adults, the flours from the five cowpea cultivars evaluated have high iron, zinc, copper, manganese, phosphorus and magnesium contents; and the flours from the cultivars BRS Cauamé and BRS Xiquexique are considered sources of calcium (Table 5).

A flour with high granulometry uniformity promote a better sensorial quality - texture, taste and visual appearance - to the final product, since it will homogeneously absorbs water, promoting a uniform cooking (SILVA et al., 2009). The whole-bean flours from cultivars BRS Guariba, BRS Xiquexique and BRS Itaim had their particles mostly retained in the $0.250-\mathrm{mm}$ mesh sieve, whereas the flours from the cultivars BRS Cauamé and BRS Novaera had their particles mostly retained in the $0.125-\mathrm{mm}$ mesh sieve (Table 6).

Table 6. Particle granulometry distribution of whole-bean flours from five cowpea commercial cultivars.

\begin{tabular}{lccccc}
\hline \multirow{2}{*}{ Whole-bean flours } & \multicolumn{5}{c}{ Percentage (\%) of material retained in each mesh opening } \\
\cline { 2 - 5 } & $2.0 \mathrm{~mm}$ & $1.0 \mathrm{~mm}$ & $0.5 \mathrm{~mm}$ & $0.25 \mathrm{~mm}$ & $0.125 \mathrm{~mm}$ \\
\hline BRS Cauamé & 0.00 & 0.00 & 0.70 & 27.90 & 71.30 \\
BRS Guariba & 0.00 & 0.25 & 1.50 & 76.10 & 22.00 \\
BRS Xiquexique & 0.00 & 0.30 & 1.80 & 59.10 & 38.80 \\
BRS Novaera & 0.00 & 0.25 & 1.50 & 23.40 & 74.70 \\
BRS Itaim & 0.00 & 0.20 & 1.00 & 54.50 & 44.20 \\
\hline
\end{tabular}

The results of the granulometric analysis were used to determine the average particle diameters of the flours (Table 7). According to Brazilian legislation, wheat flours for domestic and industrial uses must have an average particle diameter equal to or less than $250.00 \mu \mathrm{m}$ (INMETRO, 2014). The Brazilian legislation does not describe the granulometry for cowpea flour; therefore, the flours evaluated were compared to wheat flour. The whole-bean flours from the cultivars BRS Cauamé and BRS Novaera had diameters close to $250.00 \mu \mathrm{m}$. Thus, the flours from these two cultivars are indicate to totally or partially substitute wheat flour in foods, since foods produced with them tend to present similar texture to those made with wheat flour.

The water absorption index (WAI) measures the ability of the flour particles to bind to water. The WAI of the flours evaluated in this work ranged from 1.77 to $2.20 \mathrm{~g} / \mathrm{g}$ (Table 8 ).

The solubility of a product depends on its chemical constitution; its hydrophobic interactions decrease the solubility, and ionic and polar interactions allow interactions with the water molecules, thus increase the solubility (LOPES, 2010). The water solubility index (WSI) of the flours evaluated in this work ranged from 17 to $23 \%$ (Table $8)$. 
M. J. B. L. RIOS et al.

Table 7. Fineness modulus and average particle diameters of the whole-bean flours from five cowpea commercial cultivars.

\begin{tabular}{lcc}
\hline Whole-bean flours & Fineness modulus & Average particle diameter $(\mu \mathrm{m})$ \\
\hline BRS Cauamé & 1.29 & 254.10 \\
BRS Guariba & 1.79 & 359.28 \\
BRS Xiquexique & 1.63 & 321.79 \\
BRS Novaera & 1.27 & 250.97 \\
BRS Itaim & 1.57 & 308.25 \\
\hline
\end{tabular}

Table 8. Water absorption index (WAI) and water solubility index (WSI) of whole-bean flours from five cowpea commercial cultivars.

\begin{tabular}{lcc}
\hline Cultivars & WAI $(\mathrm{g} / \mathrm{g})$ & WSI $(\%)$ \\
\hline BRS Cauamé & $2.04 \pm 0.14$ & $18.40 \pm 0.01$ \\
BRS Guariba & $1.88 \pm 0.21$ & $22.40 \pm 0.01$ \\
BRS Xiquexique & $1.87 \pm 0.14$ & $17.86 \pm 0.00$ \\
BRS Novaera & $2.05 \pm 0.05$ & $18.66 \pm 0.01$ \\
BRS Itaim & $2.20 \pm 0.07$ & $20.00 \pm 0.00$ \\
\hline
\end{tabular}

Data are presented as mean $(\mathrm{n}=3) \pm$ standard deviation.

The Brazilian legislation (RDC $\mathrm{n}^{\mathrm{o}} 12$ of January 2, 2001) requires microbiological analysis of flours for the following microorganisms: Bacillus cereus, Salmonella spp. and coliforms at $45{ }^{\circ} \mathrm{C}$. According to this legislation, the maximum allowed counts are $3 \times 10^{3} \mathrm{CFU} / \mathrm{g}(\mathrm{CFU}=$ Colony
Forming Unit) for Bacillus cereus and $10^{2} \mathrm{MPN} / \mathrm{g}$ (MPN = Most Probable Number) for coliforms at $45^{\circ} \mathrm{C}$, and 0 (absence) for Salmonella spp. (AGÊNCIA NACIONAL DE VIGILÂNCIA SANITÁRIA, 2001).

Table 9. Microbiological counts in whole-bean flours from five cowpea commercial cultivars.

\begin{tabular}{lccc}
\hline Cultivars & Coliforms at $45^{\circ} \mathrm{C}(\mathrm{MPN} / \mathrm{g})$ & Bacillus cereus $(\mathrm{CFU} / \mathrm{g})$ & Salmonella $\mathrm{spp}$. \\
\hline BRS Cauamé & $<3$ & $<10$ & Absence \\
BRS Guariba & $<3$ & $<10$ & Absence \\
BRS Xiquexique & $<3$ & $<10$ & Absence \\
BRS Novaera & $<3$ & $<10$ & Absence \\
BRS Itaim & $<3$ & $<10$ & Absence \\
\hline
\end{tabular}

The results (Table 9) showed that the wholebean flours from the cowpea cultivars evaluated in this work are in accordance with the Brazilian legislation, therefore, without risk of contamination to consumers. These results also indicate that the product was developed using good manufacturing practices.

\section{CONCLUSIONS}

The whole-bean flours from the cowpea cultivars presented low moisture content in accordance with the Brazilian legislation; high protein content, providing more than $12 \mathrm{~g} / 100 \mathrm{~g}$ protein; carbohydrates providing good amount of energy; excellent mineral content; and low lipid content.

The production practices used were adequate and sufficient to ensure the microbiological quality of the whole-bean flours.

All whole-bean flours from the cowpea cultivars evaluated presented good nutritive profile and potential for use in bakery products.

The whole-bean flours from the cultivars BRS Cauamé and BRS Xiquexique are sources of calcium. The whole-bean flour from the cultivar BRS Cauamé presented the lowest lipid content, intermediate protein content $(23.88 \mathrm{~g} / 100 \mathrm{~g})$, and similar granulometry to that of wheat flour.

\section{REFERENCES}

AGÊNCIA NACIONAL DE VIGILÂNCIA SANITÁRIA. Resolução RDC $\mathbf{n}^{\circ} \mathbf{5 4}$, de 12 de novembro de 2012. Dispõe sobre o regulamento técnico sobre informação nutricional complementar. Disponível em: <http://portal.anvisa.gov.br/ documents/\%2033880/2568070/ rdc0054_12_11_2012.pdf/c5ac23fd-974e-4f2c-9fbc$48 \mathrm{f} 7 \mathrm{e} 0 \mathrm{a} \overline{3} 18 \overline{6} 4>$. Acesso em: 15 ago. 2014.

AGÊNCIA NACIONAL DE VIGILÂNCIA SANITÁRIA. Resolução RDC $\mathbf{n}^{\mathbf{0}} \mathbf{1 2}$, de 02 de janeiro de 2001. Aprova o regulamento técnico sobre padrões microbiológicos para alimentos. Disponível em: <http://portal.anvisa.gov.br/ documents/33880/2568070/ RDC_12_2001.pdf/15ffddf6-3767-4527-bfac$740 \mathrm{a} 0400829 \mathrm{~b}>$. Acesso em: 15 jun. 2013. 
AGÊNCIA NACIONAL DE VIGILÂNCIA SANITÁRIA. Resolução RDC $\mathbf{n}^{0} . \mathbf{2 6 3}$, de 22 de setembro de 2005. Aprova o regulamento técnico para produtos de cereais, amidos, farinhas e farelos. Disponível em: $\quad<$ http://portal.anvisa.gov.br/ documents/33880/2568070/RDC 263 2005.pdf/ d6f557da-7c1a-4bc1-bb84-fddf9cb846c3>. Acesso em: 19 ago. 2013.

ANDERSON, R. A. et al. Gelatinization of corn grits by Roll- and extrusion-cooking. Cereal Science Today, Minneapolis, v. 14, n. 1, p. 4-12, 1969.

CASTILHO, F.; FONTANARI, G. G.; BATISTUTI, J. P. Avaliação de algumas propriedades funcionais das farinhas de tremoço doce (Lupinus albus) e feijão guandu (Cajanus cajan (L.) Mill sp) e sua utilização na produção de fiambre. Ciência e Tecnologia dos Alimentos, Campinas, v. 30, n. 1, p. 68-75, 2010.

CEREDA, M. P.; CATÂNEO, A. Avaliação de parâmetros de qualidade da fécula fermentada de mandioca. Revista Brasileira de Mandioca, Cruz das Almas, v. 5, n. 2, p. 55-62, 1986.

FERREIRA, D. F. SISVAR: um programa para análises e ensino de estatística. Revista Symposium, Lavras, v. 6, n. 2, p. 36-41, 2008.

FREIRE FILHO, F. R. et al. Melhoramento genético. In: FREIRE FILHO, F. R.; LIMA, J. A. A.; RIBEIRO, V. Q. (Eds.). Feijão-caupi: avanços tecnológicos. Brasília: Embrapa Informação Tecnológica, 2005. v. 1, cap. 1, p. 29-92.

FROTA, K. M. G.; SOARES, R. A. M.; ARÊAS, J. A. G. Composição química do feijão caupi (Vigna unguiculata L. Walp), cultivar BRS-Milênio. Ciência e Tecnologia de Alimentos, Campinas, v. 28 , n. 2 , p. $470-476,2008$

FROTA, K. M. G. et al. Utilização da farinha de feijão-caupi (Vigna unguiculata L. Walp) na elaboração de produtos de panificação. Ciência e Tecnologia de Alimentos. Campinas, v. 30, Sup., p. 44-50, 2010.

GOMES, G. M. S; REIS, R. C.; SILVA, C. A. D. T. Obtenção de farinha de feijão-caupi (Vigna unguiculata L. Walp). Revista Brasileira de Produtos Agroindustriais, Campina Grande, v. 14, n. 1, p. 31-36, 2012.

HENDERSON, S. M.; PERRY, R. L. Agricutural process engineering. 3 . ed. Westport: AVI Publishing, 1976. 442 p. Chapter 6: Size reduction. p. $130-159$

HORWITZ, W.; LATIMER JR., G. W. Official methods of analysis of AOAC International. 18. ed. 4. rev. Gaithersburg: AOAC International, 2011. $1505 \mathrm{p}$.

INSTITUTO NACIONAL DE METROLOGIA, QUALIDADE E TECNOLOGIA - INMETRO. Regulamento técnico de identidade e de qualidade para a classificação da farinha de trigo. Disponível em: <http://www.inmetro.gov.br/ barreirastecnicas/pontofocal/..\%5Cpontofocal $\%$ 5Ctextos\%5Cregulamentos\%5CBRA_162.pdf $>$. Acesso em: 08 abr. 2014.

LACERDA, C. F. et al. Morpho-physiological responses of cowpea leaves to salt stress. Brazilian Journal of Plant Physiology, Campinas, v. 18, n. 4, p. $455-465,2006$.

LOPES, L. C. M. Determinação das melhores condições de extrusão e caracterização de farinha de feijão para utilização como ingrediente de alimentos instantâneos. 2010. 90 f. Dissertação (Mestrado em Ciência e Tecnologia de Alimentos: Área de Concentração em Ciência e Tecnologia de Alimentos) - Universidade Federal de Goiás, Goiânia, 2010.

MOUSINHO, F. E. P.; ANDRADE JÚNIOR, A. S.; FRIZZONE, J. A. Viabilidade econômica do cultivo irrigado do feijão-caupi no Estado do Piauí. Acta Scientiarun Agronomy, Maringá, v. 30, n. 1, p. 139 $-145,2008$

RAMÍREZ-CÁRDENAS, L. Biodisponibilidade de zinco e ferro, valor nutricional e funcional de diferentes cultivares de feijão comum submetidos a tratamentos domésticos. 2006. 171 f. Tese (Doutorado em Ciência e Tecnologia de Alimentos: Área de Concentração em Ciência e Tecnologia de Alimentos) - Universidade Federal de Viçosa, Viçosa, 2006.

RICE, E. W. et al. Standard methods for the examination of water and wastewater. 22. ed. Washington, DC: American Public Health Association, 2012. 1496 p

SILVA, D. J. Análise de alimentos: métodos químicos e biológicos. 1. ed. Viçosa, MG: UFV, $1981.166 \mathrm{p}$

SILVA, D. J.; QUEIROZ, A. C. Análise de alimentos: métodos químicos e biológicos. 3. ed. Viçosa, MG: UFV, 2002. 235 p.

SILVA, R. F. et al. Aceitabilidade de biscoitos e bolos a base de arroz com café extrusados. Ciência e Tecnologia de Alimentos, Campinas, v. 29, n. 4, p. 815-819, 2009 
SIMPLÍCIO, A. P. M. Desenvolvimento de pão integral enriquecido com farinha de cultivares de feijão caupi (Vigna unguiculata (L.) Walp.). 2013. 64 f. Dissertação (Mestrado em Alimentos e Nutrição: Área de Concentração em Alimentos e Nutrição) - Universidade Federal do Piauí, Teresina, 2013.

WATT, B.; MERRILL, A. L. Composition of foods: raw, processed, prepared. Washington DC:

Consumer and Food Economics Research. Divison/Agricultural Service, 1963. 